\title{
Fides et Ratio: An Early Enlightenment Defence of Non-confessional Religion by Poiret and his Circle
}

\author{
Henri Adrien Krop
}

\begin{abstract}
In 1707 an anonymous collection of treatises Fides et ratio was published in Amsterdam. The voluminous work of several authors contains a fierce critique of Locke's notion of faith and the moderate Enlightenment's conception of a reasonable Christianity. The sympathiser with mystic theology Pierre Poiret (I646-1719) wrote the general introduction. In the preface Poiret outlined a counter philosophy. However, the book deserves the interest of modern scholars because of the notions of religion and faith conceived by its authors. They are basically modern. Fides et ratio exemplifies the intense intellectual connections between Great Britain, the Netherlands and the German hinterland during the early modern period. The authors of the collection were part of an international non-denominational web. With some exceptions relations between the philosophes and the counter philosophers among the illuminati are neglected in modern research. In the final parts of this essay it will be argued that the ideas on faith and the ensuing separation of religion and the state created a common ground between Poiret and Christian Thomasius, the luminary of early German Enlightenment, who for some years had been directly influenced by the former's ideas.
\end{abstract}

\section{Keywords}

Pierre Poiret, mystic theology in early Enlightenment, critique of confessionalism and a state church

\section{Introduction}

In 1707 an anonymous collection of treatises dealing with the relationship between faith and reason was published in Amsterdam. ${ }^{1}$ The voluminous work

1) Fides et ratio collatae, ac suo utraque loco redditae, adversus principia Joannis Lockii. Insertus non paucis quibus revelationis divinae ac religionis christianae capita digniora ... explicantur. Cum accessione triplici I. De fide implicata, sive nuda. 2. De SS. Scripturarum certitudine ac sensu. 3. De perfectione et felicitate in hac vida, edidit et praefatus est Petrus Poiret (Amsterdam, 
of several authors, entitled Fides et ratio, contains a fierce critique of Locke's notion of faith and his conception of a reasonable Christianity. The former Cartesian philosopher and present sympathiser with mystic theology Pierre Poiret (I646-I7I9) wrote the general introduction. He deemed the father of British empiricism and luminary of moderate Enlightenment a personification of an impious rationalism. The subordination of faith to reason, he observed, would destroy the essentially practical and redeeming nature of faith. In the preface Poiret outlined a famous counter philosophy. However, the book deserves our interest because of the notions of religion and faith created by its authors. They are basically modern, although the authors introduced them within the context of pre-modern philosophy and mystic theology. ${ }^{2}$ These tracts with their mark of 'Old Philosophy' show the development of an individualistic - 'modern' - view of religion, well before the end of the Ancien Régime and the confessional state. Starting from this collection of tracts the first part of this essay (sections 2-5) will focus on Poiret's notion of faith and religion.

What is more, Fides et ratio exemplified the intense intellectual connections between Great Britain, the Netherlands, and the German hinterland during the early modern period. The authors of the collection were part of an international non-denominational web. Their views represent the ideas of a group of like-minded souls. Notwithstanding the important theological and philosophical differences between the dissenting 'Christians without the church' (Kolakowski) both the Jansenists in France, the Collegiants in the Netherlands, and the Pietists in Germany considered an individual inner light of the spirit to be the only true guide to religion and they all disliked orthodox theology, the established churches, and the confessional state. ${ }^{3}$ Their ideals paved the way for the modern view of religion that is free from constricting confessions and

\footnotetext{
I707). Poiret's preface is separately paginated. Although at the time a-now lost-Dutch translation appeared and in $17 \mathrm{I} 3$ an English one without the three appendices, the book nowadays is rare. See Stephan Hobhouse, 'Fides et Ratio: The Book which introduced Jacob Boehme to William Law,' The Journal of Theological Studies 37 (1935), 350-368, there 353. Five copies are preserved in Great Britain, two in the Netherlands, and about ten in Germany. For the Dutch translation: 'De vita et scriptis commentariolum,' Posthuma (Amsterdam, I72I), $\$ 57$, p. 57. A Dutch version of Poiret's biography is included in the I723 translation of L'Oeconomie Divine (see below, n. 33), separately paginated 3 I-86.

2) A context neglected by scholars with the notable exception of Gustav A. Krieg's thesis, Die Theologie Pierre Poirets, ihr Werden und Wesen (Bonn, I975), pp. 323-325.

3) On their affinities, see Heinz Schilling, 'Das konfessionelle Europa. Die Konfessionalisierung der europäischen Länder seit Mitte des I6. Jahrhundert und ihre Folgen für Staat,
} 
an established church. Arguing in this manner outmoded philosophers and religious thinkers such as Poiret happened to endorse the same comprehensive religious toleration called for by the new philosophers of the Radical Enlightenment. This coincidence between intellectual 'right' and 'left' dates from the beginning of philosophical rationalism as Marijke Spies observed: "Increasing professionalization gave rise to a relatively large middle class of institutionally trained or self-educated persons who placed ultimate faith in their own judgement. The growing emphasis on the inner religious life, observable both inside and outside the churches, and the increase in rationalism were two sides of the same individualistic coin." ${ }^{4}$ With some exceptions relations between the philosophes and the counter philosophers among the illuminati are neglected in modern research. ${ }^{5}$ In the final part of this essay (section 6) it will be argued that the ideas on faith and the ensuing separation of religion and the state created a common ground between Poiret and Christian Thomasius, the luminary of early German Enlightenment, who for some years had been directly influenced by the former's ideas.

\section{The Collection}

Fides et ratio consists of a preface written by Poiret, an anonymous main section and three appendices, anonymous as well. The main section consists of two parts: the first part summarizes in 22 theses Locke's religious epistemology and was originally written in English by a Scottish disciple of Locke. ${ }^{6}$ The second part is an elaborate refutation in 474 sections and was written in Latin. ${ }^{7}$ In the final part the writer urged upon the reader to imitate the example of the Roman Catholic mystic Antoinette Bourignon. ${ }^{8}$ This may be taken as a sign that Poiret himself was the author. For after reading some of her works he left

Gesellschaft und Kultur,' in Ausgewählte Abhandlungen zur europäischen Reformations- und Konfessionsgeschichte, ed. L. Schirn-Schütte and Olaf Mörke (Berlin, 2002), p. 697.

4) Willem Frijhoff and Marijke Spies, I650: Hard-Won Unity, trans. M. Heerspink Scholz (Assen, 2004), p. 4I9.

5) Jørn Schøsler, 'Le Christianisme Raisonnable et le débat sur le "socianisme" de John Locke dans la presse française de la première moitié du XVIIIe siècle,' Lias 2I (I994), 295-319 and Andrew C. Fix, Prophecy and Reason: The Dutch Collegiants in the Early Enlightenment (Princeton, I991), pp. 247-257.

6) 'Praefatio editoris,' Fides et ratio, \$ I 3, p. 20.

7) Ibid., $\$$ I 4, p. 20.

8) 'Animadversationes,' Fides et ratio, $\$ 47$ I, p. I77. 
the ministry in order to follow the pious virgin. ${ }^{9}$ However, both Poiret himself and his first biographer observed that he was only the editor. ${ }^{10}$ What is more, in the text the notion of faith is explained by means of the German words treu und glauben, clearly hinting at a German origin of the author. ${ }^{11}$

Three additional treatises follow the main section. According to Poiret the first treatise is the partial translation of a German tract entitled Die stete Freude des Geistes. The title, Poiret observed, would have been 'heaven on earth' if that title was not already in use for a "recently published famous and stigmatized Dutch book." 12 Here Poiret refers to the Hemel op aarde (1706), a notoriously Spinozistic work of the Zwolle minister Frederik van Leenhof (I647-I7I2). The third tract was published in German in I705 by a "lover of truth." 13 This "lover of truth" was Wolf baron von Metternich. Born about I660 he became an envoy for the three Hohenzollern rulers in the Chamber of Princes at the Imperial Diet at Regensburg. He died in I73 I. Just like Poiret, Metternich, though a protestant by descent, was deeply influenced by Roman Catholic mystics, above all Fénelon, and Madame Guyon, maintaining an eager correspondence with her, ranging from I7 4 till December I7 I6, a few weeks before her death. Their letters were written in an affectionate language and deal with all kinds of personal and spiritual matters, but they never touched upon the subject of confession or the need for conversion. Hence, Poiret and Metternich had in common that they may be called in the language of the age 'indifferentists,' that is to say persons indifferent to the diverse confessions and churches. Poiret explicitly addressed not only the members of his own confession, but all Christians whatever their confession, since "tous les honnêtes gens de tous les partis, Catholiques, Romains, Luthériens, ou Réformés, ont témoigné qu'on y trouve les vérités essentielles de la religion chrétienne, nécessaires et suffisantes au salut." 14 Hence, tolerance of every 'sect' such as practised in the free Dutch Republic is essential to true religion. ${ }^{15}$

\footnotetext{
9) 'De vita et scriptis,' \$22, p. I2. See Marjolaine Chevallier, Pierre Poiret I646-I7I9: du protestantisme à la mystique (Geneva, I994), pp. 39-40.

10) 'Praefatio editoris,' Fides et ratio, p. 5 and 'De vita et scriptis,' $\$ 57$, p. 36.

11) 'Animadversationes,' Fides et ratio, $\$$ I 57, p. 69.

12) 'Praefatio,' Fides et ratio, $\$ 23$, pp. 32-33: "libellus notus et notatus."

13) Ibid., $\$ 23$, p. 34.

14) Max Wieser, Der sentimentale Mensch (Berlin, 1924), pp. 48-49. The quotation is taken from Chevallier, Pierre Poiret (see above, n. 9), p. 85.

15) According to Wieser (ibid.) Irenicum universale oder gründliche Gewissens ruhe (Amsterdam, I702), p. 203, the German translation of La paix des bonnes ames. (The phrase not in the French original.)
} 
Although the main treatise may be attributed to Von Metternich, Poiret summarized the ideas as being his own. ${ }^{16}$ It is obvious that both Metternich and Poiret were members of a whole network of like-minded men and women who shared some basic ideas on faith and religion and kept in touch with each other beyond the national and confessional boundaries.

It might be argued that early modern philosophy and intellectual life in general was a pan-European phenomenon. This quite naturally applies to ideas expressed in Latin, the lingua franca of the educated elite, far into the eighteenth century. However, the ideas expressed in the vernacular languages also circulated smoothly. In such cases necessary translations were readily made. This applies to Poiret: of his more philosophical works such as the Cogitationes rationales, De eruditione, Vera et Cognita omnium prima, and Fides et ratio only Latin editions were published, but of his numerous popular works Latin, French, Dutch, German, and English versions are recorded. These fulfilled the need of the literate, but not academic readers. Apparently not only scholars entertained the ideals of an international Respublica litteraria, ${ }^{17}$ but also the general educated public, the readers of Le Clerc's Bibliothèque universelle et historique which reviewed books "en quelque langue qu'ils soient écrits." 18

\section{Poiret's Biography}

In order to grasp the ideas on faith and religion in Fides et ratio set forth by Poiret and his circle of friends an outline of the life and writings of the editor will be of some use. Poiret was born into a Reformed family in Metz. He studied theology at Basel, where he encountered Cartesianism. He became greatly interested in the ideas of the philosopher and according to his first biographer the reading of his works filled him with joy. He took Descartes as his guide and the Frenchman's ideas entered into every nerve of his philosophy. Poiret befriended Johann Rudolf Wettstein (I6I4-I684), the Basel professor of New Testament theology, who opposed the Consensus Helveticus, the confession of the Swiss Reformed churches, and his son Heinrich, who after the settlement of both friends in Amsterdam became his lifelong

16) 'Praefatio editoris,' Fides et ratio, $\$$ I $5-16$, pp. 2 I-23.

17) See the inaugural address of $\mathrm{H}$. Bots, Republiek der letteren, ideaal en werkelijkheid (Amsterdam, 1977).

18) H. Bots et al. (eds.), De Bibliothèque universelle et historique (I686-I693), een periodiek als trefpunt van geletterd Europa (Amsterdam, I981), p. 76. 
publisher. They shared an open dislike for the established churches. La paix des bonnes âmes, an open letter he wrote after the revocation of the Edict of Nantes, clearly illustrates Poiret's anti-confessionalism and the irenic stance of his thought. He invited the Huguenots to have no remorse if they were forced to confess or to have communion, both being only unimportant external ceremonies: "L'essentiel de la religion Chrétienne consistoit dans le coeur \& que les céremonies n'etoient un accessoire." ${ }^{19}$ Hence, true religion is of a practical nature.

In the preface of a Latin edition of Bourignon's letters Poiret argued for the primarily moral nature of her teaching. Quoting I Cor. 4,20: "The kingdom of God is not a matter of talk but of virtue," he observed that Christianity does not consist in external ceremonies, the professing of words and formularies, or believing in certain established opinions, but it is the way and means to obtain our bliss. ${ }^{20}$

After Basel he left for Heidelberg where he studied German and Dutch mystical and religious writings, such as the anonymous Het boeck der ghetuygenissen van den verborgen Acker-schat (The book of the testimonies about the treasure hidden in the field) written about I660, Tauler's Theologia Deutsch and Thomas à Kempen's Imitatio Christi, translating them all into French. In the "Avis au lecteur" of the last book Poiret explained his interest in mystical literature by underscoring their moral significance. For Thomas à Kempen's principal aim was to teach all Christians the difference between virtue and vice. By adopting Christ's way of life, man will be liberated from the tomb of sin and hatred. What is more, mystical theology is of a popular, and not of a scholarly nature. For, in order to teach the common people how to overcome the desire for evil and to free the intellect of its love of vain things, it has to be simple, without embellishment and refinement. ${ }^{21}$ However, Poiret always denied being a mys-

19) La paix des bonnes ames dans tous les parties du christianisme (Amsterdam, I687), p. 2 (Modern reprint by Marlojaine Chevallier (Geneva, I998), p. 32). Answering the objection that the adoration of bread in the mass is idolatry, Poiret observed (p. 22): "Je voudrois bien sçavoir quel mal on fait de croire que Jesus Christ soit dans l'Eucharistie. Et quand on le croid de bonne foy sur ce qu'il le peut $\&$ qu'il l'a dit sans s'alambiquer beaucoup sur le comment n'est ce-pas un éxercise admirable de foy, d'humilité \& d'abnégation admirable de la raison humaine $\&$ corrumpue?"

20) 'Ad lectorem,' Virtutum christianarum insinuatio facilis et quibisvis accomodata, ed. et praefatus Petrus Poiret (Amsterdam, I7 I I), pp. ${ }^{*} 2{ }^{2}{ }^{*} 3 \mathrm{v}$.

21) 'Avis au lecteur,' Kempis commun, ou Les quatre livres de l'imitation de Jesus-Christ, traduits pour l'edification commune de tous les Chrétien (Amsterdam, I70 I), pp. *2v-*6v. 
tical theologian. "I never wrote a work of mystical theology myself. I did not think myself capable of doing so. Even less I ever included myself among those who are enlightened." 22 He merely wrote its "historia." 23

Mystical theology is of a moral nature, since it follows from the observation of the essence of Christianity: love and peace. ${ }^{24}$ Since Poiret-and Bourignon-believed that such examples of Christian life were to be found in every church or sect, their irenism is directly linked to their interest in mystical theology.

In 1669 Poiret became a Reformed minister. However, after a spiritual crisis in 1674 he left the ministry and dedicated his life to God alone. ${ }^{25}$ Nevertheless he did not renounce the world completely and in I 677 his first philosophical work, the Cogitationes rationales de Deo anima et malo, was published in Amsterdam. The book went through three editions during his life. The first edition was a straightforward rational theology of a Cartesian mould applying the Cartesian method of clear and distinct ideas to the main theological issues. The second, completely reworked, edition shows less appreciation of human reason and Cartesianism, adding a detailed criticism of Spinoza whose philosophy symbolised the errors of reason unenlightened by the light of God. In the last edition of the Cogitationes an unfavourable survey of Bayle is added. Like Spinoza the philosophe de Rotterdam used the impious methodus curiositatis. ${ }^{26}$ The fundamental opposition of a false, 'atheistic' philosophy and real wisdom created by the light of God is the pivotal theme of Poiret's second philosophical work, De eruditione solida, superficiaria, et falsa. The book, preceded by a treatise on method, was first published in I 682 in Amsterdam.

Shortly after 1675 Poiret went to the Netherlands, where he aided Bourignon with the realisation of her plans to establish a non-confessional community

\footnotetext{
22) 'Vindiciae,' Posthuma I, 5, 6, p. 252.

23) 'Auctoris praefatio ad lectores,' Theologiae pacificae, itemque mysticae, ac hujus auctorum, idea brevior (Amsterdam, I702), p. * 4 r. See Max Wieser, Peter Poiret, der Vater der romanischen Mystik in Deutschland (Munich, I932), p. 99.

24) 'Theologiae mysticae idea generalis,' Theologiae pacificae, p. 73. In the general outline of mystical theology included in his survey of mystical authors, Poiret described as its aim the purification of man's spiritual nature by God and his unification with the Creator. In this sense mystical theology is one and the same with religion. In a stricter sense mystical theology is practised by a small group of "holy men and women." The story of the religious and spiritual life of these "religious specialists" recorded in mystical literature is an inspiring example to the other Christians.

25) 'De vita et scriptis,' $\$ 22$, p. I 2.

26) 'Dissertatio nova,' Cogitationes, 3 rd ed. (Amsterdam, I7 15 ), \$5 , p. 6.
} 
on Noordstrand, an island off the North-Frisian coast. After Bourignon's death in 1680 Poiret edited her works, which earlier had been published by Jan Rieuwerts, who published Spinoza's works as well. ${ }^{27}$ In I 688 he, like Spinoza before him, moved from Amsterdam to Rijnsburg, where among the remnants of the Collegiant movement he spent the rest of his life till his death in I7I9.

\section{General Ideas}

A survey of the general philosophical and theological ideas cherished by Poiret will be helpful as well. According to Brucker's Historia critica Poiret was a "theosophist," that is to say "a strange philosopher who consider the human intellect to be closed off from the light of truth in such a manner that the divine supernatural light is required to restore its function as principle of knowing." Hence, "only those few men beloved by God" believe themselves to be in the possession of the philosophical wisdom concealed to others. ${ }^{28} \mathrm{His}$ intellectual evolution is described in terms of an abrupt shift from Cartesianism to mysticism. "Influenced by an uneducated, zealous and visionary woman he got astray in all follies of mystical theology and destroyed with his arrows all philosophical reason and the sciences." ${ }^{29}$ According to Bayle and Le Clerc he renounced "l'esprit du monde" and become a "philosophe enthousiaste." Hazard reproduced this judgment by observing that "Madame Guyon and Poiret were by no means the least considerable of those who professed the theology of the heart. It was useless to try to put down these Enthusiasts; useless to attempt to repress them by force. As for appealing to reason, what was the use of that with people who declined to recognize that reason had any jurisdiction in the matter? (...) they came to seeking God in their own pathological disorders, in stark lunacy." ${ }^{31}$ At the end of The European mind Hazard underscored the antagonism between the sciences and Cartesian philosophy in particular on the one hand and the sentimentalism of these mystical "illuminati" on the

27) M. de Baar, 'Ik moet spreken.' Het spiritueel leiderschap van Antoinette Bourignon (I6I6I680) (Zutphen, 2004). On Rieuwertsz, see pp. 286-287.

28) J.J. Brucker, Historia critica philosophiae a mundi incunabulis ad nostram usqve aetatem deducta, 6 vols. (Leipzig, I766), 4: 644.

29) Historia critica 4, pp. 724-735.

30) G. Mori, Tra Descartes e Bayle, Poiret e la teodicea (Bologna, I990), p. I 55.

31) P. Hazard, The European mind, trans. J. Lewis May (Hammondsworth, I973), pp. 486 and 490 . 
other. In order to substantiate this claim Hazard refers to Bayle's article on Bourignon, which related some unhappy conferences of the virgin with Dutch Cartesians in Amsterdam. ${ }^{32}$

Indeed, the mature Poiret consistently rejected philosophical reason. A theology and philosophy based on reason alone barred man from realising his end. Men misguided by reason are like the prisoners in Plato's cave. On the frontispiece of De eruditione solida, superficiaria et falsa the three forms of erudition are depicted. False human knowledge is symbolized by men who have at their feet the great books of human knowledge: Homer, Ovid, Aristotle, and the Opera philosophica. The last title presumably refers to Descartes, since under this title a well-known editon of his collected works was published by Elsevier in the seventeenth century. This assumption is substantiated by a phrase in the title: "The errors of human knowledge and of Cartesianism in particular detected." At the top of a high mountain on a throne real knowledge is dwelling with the sun in his hand dissipating all obscurities and illuminating our mind by his rays. A small detail in this print, which is worthy of attention, is the few persons in the middle ascending the small path towards solid erudition. They are near a narrow gate with a knocker. The three simple persons are a humble man, a woman and a child. They symbolize the true Christian.

Poiret, however, had no sympathy with fideism, or scepticism. "Who in the possession of a healthy mind is in doubt about things which are beyond all doubt? (...) It would be blasphemous to argue that we cannot know God from his ways and his works and to blame Him by saying that no understanding is possible of the most solid and essential truths." 33 This proof is as certain as mathematical reasoning. ${ }^{34}$ On the contrary, it is rationalism which opens the gate to scepticism: "Rationalist philosophers are like men who go a few steps towards their goal, but at the first problem they encounter, they pull up and are blind standing before the truth." ${ }^{35}$ They decry human weakness, but "will be brought to their sense by sending them to cooks and gardeners." ${ }^{36}$ Only sensible persons without too much reading in ancient and modern books and

\footnotetext{
32) Dictionaire historique et critique, 4 vols. (Amsterdam, I740), i: 648-649.

33) 'Preface,' $\$$ I 8 , L'Oeconomie Divine ou système universel et démontré des oeuvres et des desseins de Dieu envers les Hommes, où l'on explique et prouve d'origine les principes et les veritez de la nature et de la grace de la philosophie (Amsterdam, I687).

34) Ibid., \$ I2: "Les témoignages que je rend à la vérité," Poiret presumed are "autant ou plus démonstrative que les vérités de la géométrie."

35) Ibid., $\$$ I 5 .

36) Ibid., $\$$ I 7 .
} 
lacking the prejudices of the schools are able to understand the truths proposed to them by comprehending the nature of things. "La critique," that is to say humanist learning is rejected. However, Poiret not only joined the tradition of the docta ignorantia, but his third main philosophical work Economie divine was explicitly aimed not at scholars, but at the literate public in general. Thanks to Poiret and others theology became a subject of discussion at courts and in salons. ${ }^{37}$

The preceding biography makes obvious that in Poiret's life the encounter with Madame Bourignon produced no abrupt shift from Cartesianism to mysticism. Notwithstanding all his criticism of human reason till the end of his life he retained his interest in philosophy. This is obvious from the Discursus praeliminaris, the introduction to the second edition of the Cogitationes rationales written in 1685 , i.e., after his rejection of philosophical reason. According to Poiret all philosophy aims at real happiness by acquiring knowledge of the Truth. ${ }^{38}$ Poiret adopted the Cartesian principle that all philosophy starts with the examination of the mind. The primary fact of consciousness is its impotence to exist by itself and by its own light. Hence, the knowledge of truth is only possible if the mind associates itself with the source of all Truth, God, error and sin being the effect of an aversion of the mind from Him. Certainty is only possible if we are overwhelmed by the absolute clarity of the divine light. The resulting absence of doubt provides us with the ultimate peace, he observed quoting Augustine's Confessiones I, I "our heart is restless, until it repose in Thee."39

With respect to this focus on the mind Cartesian and Augustinian influences intermingle. ${ }^{40}$ However, a basic Cartesian feature of Cartesianism is the highlighting of method. The mature Poiret retained this obsession. Hence, a methodical treatise, entitled De vera methodo inveniendi verum, preceded De eruditione solida. Poiret conceived his method as an emendation of Descartes's method developed in the Meditationes de Prima philosophia. The third rule formulates the Cartesian principle that the scrutiny of our consciousness is the

37) Hazard, The European mind (see above, n. 3I), p. I I o and Mori, Tra Descartes e Bayle (see above, n. 30), pp. 200-20I.

38) 'Discursus praeliminaris,' Cogitationum rationalium de Deo, anima, et malo libri quatuor, in quibus quid de hisce Cartesius, ejusque sequaces boni senserint, omnisque philosophiae certiora fundamenta, atque in primis tota metaphysica verior continentur nec non Benedicti de Spinoza Atheismus (Amsterdam, I685), p. 2.

39) 'Discursus praeliminaris,' p. 4.

40) Gustav A. Krieg, Der mystische Kreis, Wesen und Werden der Theologie Pierre Poirets (Göttingen, I979), pp. 57-61. 
commencement of all knowledge.-A Neoplatonic element in his philosophy is the overall significance he attributes to the tripartite structure of reality. For the mind presents itself as a desiring being, experiencing its deprivations and its affections. Afterwards the mind becomes conscious of its faculty to perceive objects outside the mind and finally its power to receive joy by finding peace in the objects is perceived.-The second stage of the philosophical method is that the mind by contemplating itself acquires the notion of a being that is the cause of my being and all other creatures. ${ }^{41}$ - Introspection leads to the discovery of three kinds of truths as well: spiritual or mental truths, material truths about the bodies in the natural world, and rational truths about ideas, that is to say the shadows, or lifeless pictures of things. ${ }^{42}$ These three kinds correspond with three human faculties: passive intellect, the senses, and human reason or active intellect, and three powers producing these truths: the divine light, the natural light, and the light of reason. ${ }^{43}$

By making light crucial in his epistemology, Poiret follows the Augustinian tradition of illumination claiming that all knowledge is due to an external light. By the divine light we know God and our minds, if our intellect remains passive. However, if the mind uses the light of human reason, we see only the ideas created by ourselves, pointless pictures representing nothing in reality. Hence Descartes's arbitrary notion of truth devised by human reason is to be rejected. Poiret argues for a criterion derived from the nature of the things. ${ }^{44}$ The last three rules deal with the impediments the mind encounters in knowing things. Faith being a direct relationship between God and the believer, the method implies the rejection of all traditional religious authority.

In the Preface of Fides et ratio Poiret presents an outline of his thought. In the first section he argues that eternal life is the end of the Christian religion. ${ }^{45}$ Such an eternal life consists in the perfection of the most essential parts in man. In order to acquire this perfection the restoration of the initial communication of man with God is required. The principle means of restoration is faith, produced both by God's light and love and the corresponding response of man's basic faculties: intellect, will, and desire. In spite of the actual doctrines of the different confessions, Poiret discerns in this matter a basic consensus between

\footnotetext{
41) 'De vera methodo inveniendi verum,' $\$ 6$.

42) Ibid., \$ I 9.

43) Ibid., $\$ 22$.

44) Ibid., $\$ 23$.

45) 'Praefatio editoris,' Fides et ratio, $\$$ I, p. 5.
} 
Protestants and Roman Catholics, if we take the trouble to understand their doctrines properly. ${ }^{46}$ Here, as usual, Poiret underlines the minimal role of the mind in the knowing process with the following argument: all knowledge is produced by a light shining into the intellect. "This light is either divine, or human." However, if the light is human, that is to say human reason, divine faith will never be acquired. Therefore, Poiret concluded, "the light must be altogether divine." For the knowledge human reason produces is only imaginary and false. Hence it is of no effect. ${ }^{47}$ It is Satan, who uses human reason inducing man to substitute inane means for real ones. In order to deceive men effectively, the Devil of old employed scholars and rationalist philosophers, as history demonstrates. Among the Jews there were the Pharisees and the Cabalists, among the Christians the Pelagians and the Socinians. ${ }^{48} \mathrm{How}-$ ever, this evil is not restricted to history alone, since according to Poiret in his own time this threat is spreading more and more among the Christians, among scholars in particular. The rise in Roman Catholicism of a sect of new philosophers, which prefer reason to faith-Poiret refers to Malebranche-is the Satan's doing, while Protestantism is infected by Arminianism, which subjected Revelation and Scripture to reason. One of those rationalists is Joannes Lockius, "a subtle, eloquent and methodical philosopher as well." ${ }^{49}$ According to Poiret Locke plays a part in the eternal tragedy of human history; the eternal struggle between rationalism and faith. Poiret substantiates his claim by referring to the fourth book of the Essay and The Reasonableness of Christianity, supplied by references to texts of Leclerc. ${ }^{50}$ In the fourth and last section of the Preface Poiret once again turns to the theme of method, so pivotal in Cartesianism. Here he presents his method in two steps. First, the philosopher has to free his mind from prejudices-both preconceived notions and ego-centred affects. Secondly, the philosopher is obliged to cultivate the roots of good will in him. This method is also adopted by some pagan philosophers. ${ }^{51}$ Apparently in his concept of an irenic religion Poiret even included non-Christians.

\footnotetext{
46) Ibid., $\$ 5$, p. 8 .

47) Ibid., $\$ 6$, p. 8

48) Ibid., $\$ 8$, p. Io.

49) Ibid., \$ I I, p. I 3.

50) Ibid., $\$ \mathrm{II}-\mathrm{I} 3$, pp. I $3-20$.

51) Ibid., \$29-38, pp. 43-55.
} 


\section{Locke in Fides et ratio}

In the introduction of Fides et Ratio Poiret takes Locke to task. For the latter's method is based on the rejection of the mind's innate notions and the human instincts for the truth, the good and the just. Locke pretended that every principle is either directly known by the senses or indirectly by means of reasoning. What an utter absurdity! The principles derived in this way are principia idealia, that is to say man-forged principles fabricated according to the norms of reason. Instead of the natural and solid basics of our duties a powerless and ineffective foundation is laid. What is more, Locke's denial of innate ideas misconceives the nature of the mind. Indeed, God is the creator of human nature, and in this nature He inserted his light, power, and motions, expressing in this manner his truth, goodness, and justice and enabling man to return to his origin. Here Poiret refers to the traditional doctrine of man being created in the image of God. The consequence is that according to Poiret Locke is unable to account for the notion of a natural law "written into the hearts of men," which not only the apostle St. Paul argued for, but pagan philosophers as well. He concludes by presenting two very long quotations one taken from the beginning of Cicero's Tusculan Disputations III, while the other is taken from On mysteries of the Neo-platonic third-century philosopher Iamblichus, each running for more than a page. It should be noted that apparently Poiret-by presenting these long references — readily endorsed both the dynamism and teleology of ancient, non-Christian, naturalism and knowledge about the gods coexistent with our nature. 52 "Nor should we examine [such knowledge] as though we were in a position either to assent to it or to reject it; for it is rather the case that we are enveloped by the divine presence and we are filled with it." These notions are to be adopted by all Christian philosophers. ${ }^{53}$

In the main section of Fides et ratio by an unknown Scot an outline of book IV chapter I 8 of the Essay is presented. From the fourth edition of the Essay onwards Locke added a chapter (ch. I9) denouncing enthusiasm. He observed that enthusiasm rises from "the conceits of a warm and overweening Brain," and is "founded neither on Reason nor Divine Revelation."

\footnotetext{
52) Ibid., $\$ 37$, pp. 52-53.

53) Ibid., $\$ 37$, pp. 54-55. The translation is taken from the modern English version by Emma C. Clarke et al., On the Mysteries, I (Atlanta 2003), ch. 3, p. I3. Poiret quotes from the 1678 Oxford edition. The argument confirms Mori's idea of a "regresso di Poiret verso forme di pensere pre-cartesiane," Tra Descartes e Bayle (see above, n. 30), p. I87.
} 
The Enthusiasts believe "whatever groundless opinion comes to settle it self strongly upon their Fancies, is an Illumination of the spirit of God." 54 These lines from the Essay make obvious that Locke contended with the "enthusiasm" of "Christians without the church." Since Locke and other Enlightenment philosophers focussed their philosophical energy on the denouncement of the enthusiasm of the illuminati, "enthusiasm" or "schwärmerei" is deemed by some the "anti-self" of Enlightenment. ${ }^{55}$

Although Fides et ratio was written after the publication of the fourth edition of the Essay in I700, the anonymous author merely summarised chapter i 8. He defined: "Reason as an assent to a proposition because of its own evidence," while "Faith is an assent upon the credit of God." 56 Hence faith requires revelation and testimonies. After proposition 6 the problem of false revelation is addressed, because "experience of all ages demonstrates that men have been mistaken in this affair accounting that divine revelation, which was not." 57 In order to solve this problem the Scot unambiguously established Reason as the criterion of faith: we know for certain that a revelation proceeds from God only by reason. "This certain knowledge must be attained either by reason or by Faith: not by Faith; otherwise it must presuppose itself and there will be a procession to infinity; therefore by reason." 58

After these general remarks the Scot entered into details of Locke's theory: in the case of traditional revelation, we have to know beforehand that the person whose testimony we have faith in, is sincere, not deceiving himself and knowing the right meaning of the texts. In short: the persons we believe in must be reliable and reasonable. In the case of a direct revelation by God reason has to rule out the natural and supernatural causes which otherwise might produce such a testimony. Only if I know that none of these causes did produce the testimony I have firm evidence that the revelation proceeded from God. It is obvious that this inquiry is to be made by reason. Hence, reason is the criterion by which faith is to be judged. Without this

\footnotetext{
54) An Essay concerning Human Understanding IV, I9, 7 and 6, 9.

55) J.G.A. Pocock, 'Enthusiasm: The Antiself of Enlightenment,' in Enthusiasm and Enlightenment in Europe, I650-I850, ed. Lawrence E. Klein and Anthony J. La Vopa (San Marino Cal. I998), pp. 7-28.

56) 'Theses de ratione prae fide,' Fides et ratio, pp. 3-5. The interpretations of Locke's distinction differ wildly, see David C. Snyder, 'Faith and Reason in Locke's Essay,' Journal of the History of ideas 46 (1986), p. I97.

57) 'Theses de ratione prae fide,' Fides et ratio, p. 7.

58) Ibid., p. 8.
} 
criterion it is impossible to distinguish between true and false revelation and we are a prey of every kind of prophet, "seducing spirit," or seer of visions. ${ }^{59}$

In the Animadversationes the author-Von Metternich?-rejects Locke's definition of reason on formal and material grounds. Locke violates the basic rule of logic that in a definition the definiens is convertible with the definiendum and finally the phrase "the evidence of a proposition" is obscure. ${ }^{60} \mathrm{He}$ wrongly does not take into account the different kinds of clear and distinct perception: of "the natural bodies by means of the external senses, of spiritual beings by means of the internal senses." Absent objects we perceive indirectly by means of the ideas or images left by the things in our memory. ${ }^{61}$ The author of the Animadversationes continues by distinguishing between active and passive ideas, or images. Our mind entertains passive ideas if our intellect merely contemplates the impressions the senses receive from their internal or external objects. However, we have active ideas if the intellect partly fashions the idea of an object. ${ }^{62}$

Although this epistemological theory is slightly different from Poiret's, the common ground is clear: the source of all real knowledge is the external light, which enables us to see the things as they really are and human reason a faculty, by which man is "apt to commit many errors." 63 It is obvious that after the initial pages the author lost all interest in Locke's ideas on reason and went his own way.

To Locke's definition of faith the author pays even less attention. It is a folly to call a particular act of assent the essence of faith, he argues. For assenting upon the credit of God renders the act in scholastic terms a secondary act. Ironically he calls Locke's definition a brilliant invention, to be reckoned among the novelties of this so-called most enlightened age-inventum illuminatissimi seculi - this text might well be one of the first to use the word in a cultural-historical sense. ${ }^{64}$ The weakness of Locke's definition induces the author of the Animadversationes to present another definition by starting from a natural law premise. The all-wise God created man for a perfect end. But without giving man the means and the faculties to achieve his goal, God would not be all-good. A denial of this premise would be blasphemy. Hence man is

\footnotetext{
59) Ibid., p. I 8.

60) 'Animadversationes,' Fides et ratio, pp. 25-26.

61) Ibid., pp. 28-29.

62) Ibid., pp. 30-32.

63) Ibid., pp. 33 and 36.

64) Ibid., p. 38.
} 
created both with a natural inclination towards the Good and a natural instinct to know God. ${ }^{65}$ The knowledge of God resulting from this tendency has to be called faith, since it is given to man by the divine light. Faith in its basic sense implies piety, fidelity, simplicity, and the love of God. Hence, faith is primarily a habit guiding man towards his end and does not require insight into deep mysteries or controversies. He rejected the traditional orthodox view identifying the substance of faith as the assent to a creed consisting of a greater of smaller number of articles. "He who properly understood all this, easily acknowledges the immense absurdity of reducing the divine faith to some articles to be adhered to by force, for it is only God who is inviting us to know all the things necessary, to refrain from arrogance, from deciding all things in a high-handed manner and from censuring one's brother in one way or the other." 66

On the one hand Reformed orthodoxy turns the medicine of faith into a poison by seeking a vain comfort in the most pernicious fiction of predestination, ${ }^{67}$ on the other hand Locke's definition of faith is off the mark. ${ }^{68}$ We do not believe by a man's authority, but because he inspires piety. This argument amounts to a strong plea to the reliance upon one's own religious experiences produced by the divine light in our soul. ${ }^{69}$ According to the Animadversationes the Biblical principle "a tree is known by its fruit" applies to revelation, that is to say the experience of God's redeeming presence in our mind. ${ }^{70}$ In Fides et ratio it is the individual who is facing the problem of demarcation between faith and unbelief in his own life. However, Locke dealt with the problem from a social point of view: what is the creed one must believe to be admitted to the Church.

\section{The Illuminate Concept of Faith and Modernity}

A basic claim Jonathan Israel advances in Enlightenment Contested is the duality of a moderate and a radical Enlightenment. The two versions of Enlightenment thought represent two rival interpretations of man and the universe: one seeking for comprise between tradition and renewal, between Christian

\footnotetext{
65) Ibid., p. 45.

66) Ibid., p. I 2 I.

67) Ibid., p. 99.

68) Ibid., p. I 2 I.

69) Ibid., pp. I 27-I 28 .

70) Ibid., p. I 47.
} 
faith and philosophy, and the other being radical, democratic, and egalitarian. This rivalry, Israel observed, is reflected in the diverse notions of toleration. The moderate Enlightenment proclaimed a limited notion of toleration. Locke's theory, for example, stems form theological premises, toleration being essentially an "immunity from the form of worship otherwise generally prescribed by the sovereign, through the state church." The Radical Enlightenment, however, proclaimed a comprehensive toleration, considering the conscience of each man to be the unassailable sanctuary of his religious and moral truth. ${ }^{71}$ Both versions of Enlightenment, Israel urged, raised the anger of a still more widely supported Counter-Enlightenment, totally rejecting reason and decrying philosophy as a whole. ${ }^{72}$

According to Israel Poiret is a staunch partisan of Counter-Enlightenment. In Radical Enlightenment he had observed that Poiret from a luminary of Cartesianism became a mystical recluse who "recoiled from Cartesianism and all philosophy based on reason and science. Henceforth, he launched a oneman crusade from his retreat in the Dutch village of Rijnsburg (...) against modern philosophy and the entire Early Enlightenment."73 Pascal and Bossuet launched comparable assaults on rational theology.

Although Israel's scheme is, in general, extremely useful, it precludes us from acknowledging some affinities with respect to faith and religion between Poiret and his circle on the one hand and some Enlightenment (moderate) philosophers on the other. First, it should be noted that Poiret's intellectual background was markedly different from Pascal's and Bossuet's. His ideas were rooted in the religious movement originating from the Reformation, asserting that the Reformation was incomplete if in religious life the original direct and substantially free relationship between God and the individual believer was not restored. This movement was in Germany from Luther onwards denounced by Lutheran orthodoxy and was called in Germany by the abusive term schwärmerei, or elsewhere "enthusiasm." It consisted of Anabaptists, Quakers, Collegiants, and afterwards Pietists, groups Kolakowski called "Christians without a church." The link of Poiret with this movement is

\footnotetext{
71) J. Israel, Enlightenment Contested, Philosophy, Modernity and the Emancipation of Man I670-I752 (Oxford, 2006), pp. I38-I40.

72) Ibid., pp. 38-40.

73) J. Israel, Radical Enlightenment, Philosophy, Modernity and the Making of Modernity I650-1750 (Oxford, 200I), p. 474. Cf. Enlightenment Contested (see above, n. 7I), p. 509, where Israel approvingly quotes Diderot's words: "Pierre Poiret perverted theology, blighted philosophy, and generally clouded the human mind."
} 
obvious. For in the second part of his life he lived among people who attached little importance to the main confessions, seeking to practise a private inward Christianity and to promote an anti-dogmatic religiosity. Poiret's intellectual endeavours to conceptualise such forms of belief were readily accepted in German pietism and other adversaries of orthodoxy.

Secondly, it may be argued that the opposition between the philosophes and the "enthusiasts" was not always clear-cut. The jurist and philosopher Christian Thomasius (I655-I728), who long has been regarded as one of the first and most influential representatives of the early Enlightenment, was during the I690s interested in Poiret's ideas and even wrote a sympathetic introduction to the 1694 German edition of De eruditione. ${ }^{74}$ After a general survey of his thought Thomasius turns to his definition of faith. Happily, he urged, Poiret did not focus on the "unity of a confession" but on the "unity of love of God." Therefore "among the faithful there is no sect or Church, but they are all brothers." 75 Hence Thomasius adopted the irenism of the "Christians without the Church" and expressed his feelings of revulsion against the theological controversies on the Eucharist. "These clerics abjure reason and love" and deceive the laity ${ }^{76}$ Doctrines are only metaphors, which are derived from the things familiar to man and represent God "imperfectly and improperly." 7

Moreover, although Thomasius rejected Poiret's physics, he wholeheartedly agreed with his theistic epistemology. ${ }^{78}$ The base of all knowledge is our desire to know God and his Creation, he urged, a desire frustrated by Sin and the affects. Only God is able to remove these impediments, so the divine light is required in order that we know. Where human reason is active, it leads the mind, passive by its own nature, into error. In this manner Thomasius adopted Poiret's quietism: our bliss, the "intellectual love of the mind is a gift of God. We are unable to acquire this state on our own account, as Spinoza maintained. The divine wisdom is in the eyes of the world foolishness." The manifest simplicity of the Bible resists all efforts to accommodate the divine message

\footnotetext{
74) Thomas Ahnert, 'Enthusiasm and Enlightenment: Faith and Philosophy in the Thought of Christian Thomasius,' Modern Intellectual History 2 (2005), I 53-I77, there I 53-I 54.

75) 'Dissertatio ad Petri Poireti libros de eruditione,' Programmata Thomasiana et alia scripta similia breviora conjunctim edita cum notis (Halle/Leipzig, I724), p. 320. About Poiret he approvingly observed, p. 3 I I: "de secta noli esse soliticus," hence "nec pietas nec sapientia sectam curat." A member of any church whatsoever is a real Christian "si Deum timet et in viis ejus ambulat."

76) 'Dissertatio ad Petri Poireti libros de eruditione,' p. 334: "quicquid delirarunt hi clerici."

77) Ibid., p. 3 I 8.

78) Ibid., p. 326.
} 
to whatever philosophy. ${ }^{79}$ Hence, both Thomasius and Poiret attempted to separate religious truth from the pursuit of secular erudition and true religion from the established churches.

Thomasius's views exposed him to the charge of enthusiasm from the orthodox theologians and he modified his ideas from the I 700 s onwards.$^{80}$ In I708 Thomasius wrote a new introduction to Poiret's De eruditione, once more in print. In the first section he added to Poiret's theory of the three kinds of knowledge the opposition between natural and theological erudition. ${ }^{81}$ The first kind concerns human happiness in this life, the second human bliss in the afterlife. What is more, Thomasius now opposed mystical theology being "contaminated by the pagan philosophy of Plato." The writings of Antoinette Bourignon once acclaimed were now described as "dangerous and leading to enthusiasm." ${ }^{2}$ However, Thomasius did not consider Poiret himself to be an enthusiast, although the latter's doctrine does not provide for the means to distinguish between real faith and this kind of superstition. ${ }^{83}$

Modern commentators argued that if Thomasius was influenced by the religious mysticism of the "Christians without the church." This influence lasted only briefly in the I 690s. ${ }^{84}$ However, notwithstanding Thomasius's incisive critique of "mystical theology," he clearly continued to share the ideas on religion, church and faith cherished by Poiret and his circle. ${ }^{85}$ Arguing for a "free confession, and a church merely consisting of a free gathering of the faithful," he concluded that religion is simple and easily to be learned. ${ }^{86}$ Thomasius's continued sympathy for these religious ideas is obvious from his Cautions with respect to the principles of jurisprudence. Although in the Preface he once more stated his changed opinion on mystical theology, he held on to his conviction

\footnotetext{
79) Ibid., p. 340.

80) See for example Ahnert, 'Enthusiasm and Enlightenment' (see above, n. 74), I67-173.

81) 'Dissertatio nova ad Petri Poireti libros de eruditione,' Programmata Thomasiana (see above, n. 75), pp. 609-610.

82) Ibid., p. 643.

83) Ibid., p. 639.

84) Ahnert, 'Enthusiasm and Enlightenment' (se above, n. 74), I 54.

85) Lisolette Neisser, Christian Thomasius und seine Beziehungen zum Pietismus (Munich, I 928), pp. I 5-3 I and Frank Grunert, 'Antiklerikalismus und christlicher Anspruch im Werk von Christian Thomasius,' in Les lumières et leur combat, ed. Jean Mondot (Berlin, 2004), pp. 39-56.

86) Horst Dreitzel, 'Christliche Aufklärung durch fürstlichen Absolutismus. Thomasius und die Destruktion des frühneuzeitlichen Konfessionsstaates,' in Christian Thomasius (I6551728), ed. Friedrich Vollhardt (Tübingen, 1997), p. 34.
} 
that all knowledge should be useful, that is to say ultimately leading to man's end, felicity and eternal bliss satisfying our real desires. However, our natural faculties are darkened by sin. Our folly, therefore, exists by nature. That is why "our longing for the true good, being the primary part of living knowledge is impossible without insight into our misery." ${ }^{77}$ Such recognition requires contrition. The most important means to achieve wisdom Thomasius continues to maintain even after his withdrawal from pietism, is prayer, complete bliss being a supernatural gift from God. In this religious epistemology both pagan philosophy and scholasticism are rejected. Hence Thomasius admonished the scholar to read the Bible and neglect the modern "Tullians and Macchiavellians." 88

In religion all men are equal and the hierarchies in the established churches are to be rejected. One of the secrets of such an ecclesiastical Papism is the extortion of power from the faithful, pretending that "only the acts of the clergy glorify God." ${ }^{89}$ Thomasius also stood by Poiret's irenism. The theologian had to practise piety and refrain from all hatred of heretics, since controversies in religion are generally caused by philosophical doctrine. The only decisive criterion for faith is our own conscience. ${ }^{90}$

Continuing to adhere to such ideas, it is no surprise that Thomasius was still willing to recommend De eruditione: "We confess to finding many excellent things in these books": ${ }^{91}$ the need to moderate the claims of reason, and to reject current philosophy (communis philosophia).92 As before Thomasius remained committed to a docta ignorantia, since reason obscures the divine mysteries and he still joined Poiret in his struggle against "vain speculation," that is to say the investigation of unknowable and useless things. This learned ignorance implies that all men should be granted the liberty to philosophize. ${ }^{93}$

87) Cautele circa precognita jurisprudentice in usum auditorii Thomasiani (Halle, I7Io), I, p. I6: "desiderum veri boni tanquam pars prima cognitionis vivae sine agnitione propriae miseriae esse nequit."

88) Ibid., II, p. 35 .

89) Ibid., I, p. 6.

90) Ibid., XIX, pp. 322, 326, 33I.

91) 'Dissertatio nova,' p. $62 \mathrm{I}$.

92) Ibid., p. 654.

93) Ibid., p. 6r 3. In his 'Defensio methodi inveniendi verum,' Posthuma, p. I48, Poiret responded by arguing that he did not reject reason at all. For he did supply a criterion for distinguishing between real divine revelations and enthusiasm: unanimity. Assuming that the mind is really free from human fantasies, the testimonies of the divine light will be speaking with one voice, which proclaims the simple moral message of Christ. 
Thomas Ahnert concluded that in Thomasius philosophical and religious ideas were "closely dependent on each other" and more in general that in the first quarter of the eighteenth century in Germany no significant thinker believed that "reason could be the measure of revealed truth." His religious ideas contributed directly to some of "the main intellectual currents of the German Enlightenment."94

The Enlightenment put an end to a society based on tradition and confession sanctioned by State, Church, and University. ${ }^{95}$ The fraud and unchristian ideological base of the Old Regime Thomasius summarized by writing: "Faith is equated with a creed and Catholicity with all articles the subjects are forced to believe"; ${ }^{96}$ that is to say sanctioned by the State.

Thus, notwithstanding their intellectual and philosophical differences, both the enlightened philosophes and the illuminati of Poiret's circle had a common cause: the struggle against the confessional State and State enforced ecclesiastical confessions. The renewal of religion aspired to by non-confessional denominations became possible after "the structural necessity of the coalition between the early modern state and confessionalism had vanished." ${ }^{\prime 7}$ Hence, the destruction of established confessions and a comprehensive tolerance was pleaded for by both the philosophes and the "enthusiast" religious groups Poiret belonged to.

$$
\begin{array}{r}
\text { Dr. Henri A. Krop } \\
\text { Associate Professor in the History of Philosophy } \\
\text { Faculty of History and Arts } \\
\text { Erasmus University Rotterdam, P.O. Box I738, NL-300o DR Rotterdam } \\
\text { krop@fwb.eur.nl }
\end{array}
$$

\footnotetext{
94) Ahnert, 'Enthusiasm and Enlightenment' (see above, n. 74), I73-175.

95) Israel, Radical Enlightenment (see above, n. 73), pp. 3-I 4.

96) Christian Thomasius, Theses inaugurales de jure principis circa haereticos (Halle, 1697), p. 7.

97) Schilling, 'Das konfessionelle Europa' (see above, n. 4), pp. 696-697.
} 
